\title{
Implications of Combining Ability among the Single Cross Hybrids for Yield and Quality Attributes in Brinjal (Solanum melongena L.)
}

\author{
P.K. Yadav ${ }^{1}$, R.K. Dubey ${ }^{1}$, Sanket Kumar ${ }^{1}$, Yadav Ram $^{2}$ and Maneesh Kumar Singh ${ }^{2 *}$ \\ ${ }^{1}$ Department of Vegetable Science, College of Horticulture and Forestry, Central agricultural \\ University, Pasighat, 791102, Arunachal Pradesh, India \\ ${ }^{2}$ ICAR-Indian Institute of Vegetable Research, Varanasi-221305, Utter Pradesh, India \\ *Corresponding author
}

\section{A B S T R A C T}

The present investigation was undertaken for combining ability studies on quantitative and qualitative traits at C.H.F., CAU, Pasighat, A.P. The $28 \mathrm{~F}_{1}$ hybrids were developed by

Keywords

Brinjal, Hybrids, gca and sca effects, Fruit yield, Quality

Article Info

Accepted:

28 September 2017

Available Online:

10 October 2017 crossing 8 diverse brinjal genotypes/varieties in half diallel fashion. The variances due to GCA and SCA were significant for most of the characters indicating the importance of both additive and non-additive gene action in the inheritance of these characters. The highest gca effect for fruit yield was found in CHFB-6 (0.52) and Swarna Pratibha (0.44).Earliest flowering and harvesting was found in CHFB-7 x Solanum gilo with a sca value of -5.59 and -5.81 , respectively. Pant Rituraj x CHFB-6 and Pant Rituraj x CHFB-7 were showed the significant response in fruit yield per plant with other characters (Plant height, number of seeds per fruit, solasodine and anthocyanin content) for sca effects. Swarna Pratibha x Pusa Purple Long was found significant sca effects for fruit yield per plant including qualitative traits. These hybrids can be used for further breeding programme regarding fruit yield, quality traits and earliness. Therefore, the current study could be evidence for hybrid breeding approaches that strengthens in improving yield, earliness together with quality traits.

\section{Introduction}

Brinjal (Solanum melongenaL. $2 \mathrm{n}=2 \mathrm{x}=24$ ) is one of the most popular and commercially cultivated, annual, herbaceous vegetable, grown in tropical and subtropical regions worldwide (Kumar et al., 2012). It is estimated that the total brinjal area and production in India were 0.71 million hectares and 13.5 million tonnes, respectively (Anonymous, 2014). In most of the countries, brinjal is the major component of the human diet. It is rich source of protein, $\mathrm{P}, \mathrm{Fe}, \mathrm{Ca}, \mathrm{K}$, $\mathrm{Mg}, \mathrm{Na}$ and fibre (Nyadanu and Lowor, 2015). It has medicinal value for asthma, allergic rhinitis, constipation, skin infections, joint pains, dyspepsia and rheumatic diseases (Nwodo et al., 2011).

It is impossible to have one common cultivar to suit different localities and local preferences. So, there is required to improve the yield potential by developing hybrids and its derivatives of brinjal through hybridization (Sherly, 2007). The combining ability analysis is an important tool in preferring suitable parents for hybridization and superior cross combinations through general 
combining ability (GCA) and specific combining ability (SCA), respectively (Sharma et al., 2016). Therefore, finding out the good combiners and crosses through the combining ability analysis are the two main objectives of present study.

\section{Materials and Methods}

The present experiment was conducted at Vegetable Experimental Farm, Department of vegetable Science, C.H.F., C.A.U., Pasighat, East Siang, Arunachal Pradesh, India. The experimental materials for the present study comprised of eight elite diverse homozygous genotypes/varieties of brinjal parental lines (Swarna Pratibha, NDB-3, Pant Rituraj, Pusa Purple Long, BR-112, CHFB-6, CHFB-7 and Solanum gilo), were crossed in half diallel technique excluding reciprocals [n(n-1)/2] during Rabi, 2014-2015. The parents and hybrids were evaluated in the successive year (2015-16).Observations were recorded on five randomly selected plants from each hybrids in each replication. The recorded observations were averaged to get mean values. Analysis of variance for Randomized Block Design was carried out according to following procedure as suggested by Gomez and Gomez (1983). The combining ability analysis for different characters was carried out according to the method 2 model 1 of Griffing (1956).

\section{Results and Discussion}

The mean square due to general and specific combining ability variances presented in table 1. It is evident from the table that variances due to GCA and SCA were significant for all the characters except variance due to GCA and SCA for solasodine content and variance due to GCA for plant height, thus indicating the importance of both additive and nonadditive gene action in the inheritance of these characters. The results are in the accordance with Dubey et al., (2014).

\section{General combining ability effects of the parents}

The vital choice of parents to be used in a breeding programme is determined by per se performance and their behaviour in hybrid combination. Out of eight parents, the parents Solanum gilo (2.19) and Swarna Pratibha $(0.97)$ were identified good general combiners for maximum plant height. Similar results were also expressed by Mishra et al., (2013). CHFB-6 and BR-112 were found good general combiners as these parents had significant negative gca effects for earliness traits i.e., days to first flowering and days to first fruit harvest. The observations for days to first flowering also accordance with Dharwad et al., (2011) and Kumar and Arumugam (2013).

Parents NDB-3(3.62), Pusa Purple Long (3.08) and Swarna Pratibha (1.71) were recognized as significant positive general combining ability effects for fruit length. However, for fruit girth, parents BR112(0.99), Pant Rituraj (0.93) and CHFB$7(0.74)$ were established good general combiners. Uddin et al., (2015) also reported the gca effects for fruit length and girth. For number of seeds per fruit, highest significant positive gca effect was observed in BR112(129.66) followed by CHFB-6 (89.12) and Pant Rituraj (73.19), showing the good general combiners. These kind of results were also reported by number of seeds per fruit. The best general combiners for fruits yield per plant recorded in CHFB-6 (0.52) followed by Swarna Pratibha (0.44) and Pant Rituraj (0.43). Similar findings also reported by Singh and Maurya (2004) and Ansari and Singh (2014).

Parent CHFB-7(0.66), Solanum gilo (0.32) and BR-112(0.24) was identified as it had significant positive gca effects for solasodine content. For total phenol content, Swarna 
Pratibha, BR-112 and Pant Rituraj showed good gca effects in desirable direction. However, the parents CHFB-6(104.36) and BR-112(35.69) were found good general combiners for anthocyanin content have significant positive gca effects (Table 2). Kumar et al., (2012) also observed the corresponding findings for total phenol and anthocyanin content. Among the parental lines, CHFB-6 emerged as the outstanding parent registering significantly positive gca effect for fruit yield per plant and related traits. Pant Rituraj, Swarna Pratibha and BR112 also found good combiner for quality parameters including fruit yield per plant, earliness and maturity traits.

Table.1 Analysis of variance (mean squares) for combining ability in an 8 x 8 cross of brinjal

\begin{tabular}{|c|c|c|c|c|c|c|c|c|c|c|c|}
\hline $\begin{array}{c}\text { Source of } \\
\text { variation }\end{array}$ & d.f. & $\begin{array}{c}\text { Plant } \\
\text { height }\end{array}$ & $\begin{array}{c}\text { Days to } \\
\text { first } \\
\text { flowering }\end{array}$ & $\begin{array}{c}\text { Days to } \\
\text { first } \\
\text { fruit } \\
\text { harvest }\end{array}$ & $\begin{array}{c}\text { Fruit } \\
\text { length }\end{array}$ & $\begin{array}{c}\text { Fruit } \\
\text { girth }\end{array}$ & $\begin{array}{c}\text { Fruit } \\
\text { yield per } \\
\text { plant }\end{array}$ & $\begin{array}{c}\text { Number } \\
\text { of seeds } \\
\text { per fruit }\end{array}$ & $\begin{array}{c}\text { Solasodin } \\
\text { e content }\end{array}$ & $\begin{array}{c}\text { Total } \\
\text { phenol } \\
\text { content }\end{array}$ & $\begin{array}{c}\text { Anthocyanin } \\
\text { content }\end{array}$ \\
\hline GCA & 7 & 16.21 & $47.78^{* *}$ & $51.79 * *$ & $\begin{array}{c}65.61^{*} \\
*\end{array}$ & $8.50^{* *}$ & $1.89^{* *}$ & $\begin{array}{c}139514 . \\
89 *\end{array}$ & 0.55 & $\begin{array}{c}1415.77^{*} \\
*\end{array}$ \\
\hline SCA & 28 & $\begin{array}{c}23.95^{*} \\
*\end{array}$ & $15.59^{*}$ & $17.01^{*}$ & $5.60^{* *}$ & $0.88^{* *}$ & $0.70^{* *}$ & $\begin{array}{c}38836.9 \\
2 * *\end{array}$ & 0.31 & $810.61^{* *}$ & $6416.47^{* *}$ \\
\hline Error & 70 & 9.13 & 8.82 & 9.32 & 0.43 & 0.05 & 0.03 & 869.10 & 0.00 & 2.13 & 9.59 \\
\hline
\end{tabular}

Table. 2 Estimates of GCA effects of parents in an 8 x 8 cross in brinjal

\begin{tabular}{|c|c|c|c|c|c|c|c|c|c|c|}
\hline Parents & $\begin{array}{r}\text { Plant } \\
\text { height }\end{array}$ & $\begin{array}{l}\text { Days to first } \\
\text { flowering }\end{array}$ & $\begin{array}{l}\text { Days to first } \\
\text { fruit harvest }\end{array}$ & $\begin{array}{l}\text { Fruit } \\
\text { length }\end{array}$ & $\begin{array}{l}\text { Fruit } \\
\text { girth }\end{array}$ & $\begin{array}{c}\text { Fruit } \\
\text { yield } \\
\text { per } \\
\text { plant }\end{array}$ & $\begin{array}{c}\text { Number of } \\
\text { seeds per } \\
\text { fruit }\end{array}$ & $\begin{array}{c}\text { Solasodine } \\
\text { content }\end{array}$ & $\begin{array}{c}\text { Total } \\
\text { phenol } \\
\text { content }\end{array}$ & $\begin{array}{c}\text { Anthocyan } \\
\text { in } \\
\text { content }\end{array}$ \\
\hline $\begin{array}{l}\text { Swarna } \\
\text { Pratibha }\end{array}$ & 0.97 & $3.06 * *$ & $3.08 * *$ & $1.71^{* *}$ & -0.08 & $0.44 * *$ & $42.09^{* *}$ & -0.33 & $18.20 * *$ & $-50.63 * *$ \\
\hline NDB-3 & 0.65 & 0.96 & 1.12 & $3.62 * *$ & $-1.51^{* *}$ & $-0.11^{*}$ & $-190.19 * *$ & -0.30 ** & $-5.75^{* *}$ & $-10.09^{* *}$ \\
\hline Pant Rituraj & -0.42 & -0.28 & -0.48 & $-2.42 * *$ & $0.93 * *$ & $0.43^{* *}$ & $73.19^{* *}$ & $-0.06^{* *}$ & $6.64 * *$ & $-16.10 * *$ \\
\hline $\begin{array}{c}\text { Pusa Purple } \\
\text { Long }\end{array}$ & -0.30 & 1.42 & 1.35 & $3.08 * *$ & $-1.10 * *$ & $-0.58^{* *}$ & $-38.39 * *$ & $0.15 * *$ & $4.14 * *$ & $-5.12 * *$ \\
\hline BR-112 & -1.22 & $-2.04 *$ & $-1.92 *$ & $-1.01 * *$ & $0.99 * *$ & 0.90 & $129.66^{* *}$ & $0.24 * *$ & $10.74 * *$ & $35.69^{* *}$ \\
\hline CHFB-6 & -0.05 & $-4.04^{* * *}$ & $-4.35^{* *}$ & 0.22 & $0.25 * *$ & $0.52^{* *}$ & $89.12^{* *}$ & -0.08 *** & $-4.95 * *$ & $104.34 * *$ \\
\hline CHFB-7 & $-1.84 *$ & 0.73 & 0.85 & $-2.29 * *$ & $0.74 * *$ & $-0.26^{* * *}$ & $53.52^{* * *}$ & $0.66^{* *}$ & $-16.11 * *$ & $-15.03^{* *}$ \\
\hline Solanum gilo & $2.19 *$ & 0.19 & 0.35 & $-2.90 * *$ & -0.22 & $-0.54 * *$ & $-158.99 * *$ & $0.32 * *$ & $-12.92 * *$ & $-43.05 * *$ \\
\hline SE (Gi) & 2.11 & 2.08 & 2.14 & 0.46 & 0.16 & 0.12 & 20.63 & 0.02 & 1.02 & 2.17 \\
\hline $\mathrm{SE}(\mathbf{G i}-\mathbf{G j})$ & 3.20 & 3.14 & 3.23 & 0.70 & 0.24 & 019 & 31.18 & 0.03 & 1.55 & 3.28 \\
\hline
\end{tabular}


Table.3 Estimates of SCA effects of $\mathrm{F}_{1}$ hybrids in Brinjal

\begin{tabular}{|c|c|c|c|c|c|c|c|c|c|c|}
\hline Crosses & $\begin{array}{c}\text { Plant } \\
\text { height }\end{array}$ & $\begin{array}{c}\text { Days to first } \\
\text { flowering }\end{array}$ & $\begin{array}{c}\text { Days to } \\
\text { first fruit } \\
\text { harvest }\end{array}$ & $\begin{array}{l}\text { Fruit } \\
\text { length }\end{array}$ & $\begin{array}{l}\text { Fruit } \\
\text { girth }\end{array}$ & $\begin{array}{l}\text { Fruit } \\
\text { yield } \\
\text { per } \\
\text { plant }\end{array}$ & $\begin{array}{l}\text { Number of } \\
\text { seeds per } \\
\text { fruit }\end{array}$ & $\begin{array}{c}\text { Solasodine } \\
\text { content }\end{array}$ & $\begin{array}{c}\text { Total } \\
\text { phenol } \\
\text { Content }\end{array}$ & $\begin{array}{c}\text { Anthocyanin } \\
\text { content }\end{array}$ \\
\hline $\mathrm{P}_{1} \times \mathrm{P}_{2}$ & 4.47 & -2.36 & -2.14 & -0.12 & 0.39 & $1.03 * *$ & $-204.66 * *$ & $0.10^{* * *}$ & $-33.10^{* *}$ & $39.96 * *$ \\
\hline $\mathrm{P}_{1} \times \mathrm{P}_{3}$ & -3.63 & 0.54 & 1.46 & $-2.15 * *$ & $-0.87 * *$ & -0.31 & $117.97 * *$ & $-0.24 * *$ & $12.23 * *$ & $-28.25 * *$ \\
\hline $\mathrm{P}_{1} \times \mathrm{P}_{4}$ & 0.97 & -0.83 & -0.38 & $1.69 * *$ & $2.48 * *$ & $0.85^{* *}$ & $351.54 * *$ & -0.04 & $40.95 * *$ & $8.31 * *$ \\
\hline $\mathrm{P}_{1} \times \mathrm{P}_{5}$ & 1.40 & $6.97 *$ & $7.22 *$ & $-1.35 *$ & $1.06 * *$ & $0.55^{* *}$ & $389.51 * *$ & $-0.45 * *$ & $35.12 * *$ & $-71.47 * *$ \\
\hline $\mathrm{P}_{1} \times \mathrm{P}_{6}$ & -2.25 & 4.97 & 4.32 & $1.78^{* *}$ & $-0.55^{*}$ & $0.72 * *$ & -40.29 & $-0.06^{*}$ & $9.62 * *$ & $36.04 * *$ \\
\hline $\mathrm{P}_{1} \times \mathrm{P}_{7}$ & -4.76 & 2.21 & 2.46 & -0.76 & $-0.66 * *$ & -0.04 & -8.36 & $-0.29 * *$ & $-3.18 *$ & $59.85 * *$ \\
\hline $\mathrm{P}_{1} \times \mathrm{P}_{8}$ & -2.89 & -1.26 & -1.38 & $-3.72 * *$ & $-1.94 * *$ & $-0.92 * *$ & $-126.53 * *$ & -0.05 & $8.93 * *$ & $-30.97 * *$ \\
\hline $\mathrm{P}_{2} \times \mathrm{P}_{3}$ & -4.81 & 0.64 & 0.09 & -0.67 & -0.20 & $-0.34 *$ & 31.91 & $-0.21 * *$ & $50.36^{* *}$ & $-69.72 * *$ \\
\hline $\mathrm{P}_{2} \times \mathrm{P}_{4}$ & 4.46 & -3.39 & -3.08 & -1.00 & $0.49 *$ & $0.41 *$ & -45.53 & $-0.43 * *$ & $35.16^{* *}$ & $-97.85 * *$ \\
\hline $\mathrm{P}_{2} \times \mathrm{P}_{5}$ & -5.24 & -3.59 & -3.48 & $2.74^{* *}$ & $-1.63 * *$ & -0.06 & -9.89 & $-0.19 * *$ & $-22.56^{* *}$ & $66.62 * *$ \\
\hline $\mathrm{P}_{2} \times \mathrm{P}_{6}$ & 2.26 & $8.41 * *$ & $8.96^{* *}$ & $1.41 *$ & -0.11 & -0.13 & $72.31 *$ & $0.24^{* *}$ & $-11.37 * *$ & $75.85^{* *}$ \\
\hline $\mathrm{P}_{2} \times \mathrm{P}_{7}$ & -1.32 & 4.31 & 3.09 & -0.65 & -0.16 & $0.56^{* *}$ & $91.57 * *$ & $-0.10 * *$ & $-13.65^{* *}$ & $37.91 * *$ \\
\hline $\mathrm{P}_{2} \times \mathrm{P}_{8}$ & 0.45 & 5.17 & 5.59 & $4.99 * *$ & $-0.68 * *$ & $-0.34 *$ & 19.74 & $-0.33 * *$ & $-6.48 * *$ & $18.88 * *$ \\
\hline $\mathrm{P}_{3} \times \mathrm{P}_{4}$ & -3.48 & 4.51 & 4.19 & $3.48 * *$ & $-0.72^{* * *}$ & $-0.41 *$ & -24.56 & $-0.81 * *$ & $-54.39 * *$ & $139.18 * *$ \\
\hline $\mathrm{P}_{3} \times \mathrm{P}_{5}$ & -1.49 & -2.03 & -2.54 & -0.22 & $0.41 *$ & -0.02 & $330.41 * *$ & $0.39 * *$ & $27.09 * *$ & $-86.09 * *$ \\
\hline $\mathrm{P}_{3} \times \mathrm{P}_{6}$ & $12.12^{* *}$ & -0.69 & -1.11 & -0.03 & -0.20 & $1.96^{* * *}$ & $65.61 *$ & $0.60^{* * *}$ & $9.63 * *$ & $65.87 * *$ \\
\hline $\mathrm{P}_{3} \times \mathrm{P}_{7}$ & 2.97 & -1.46 & -0.98 & 0.61 & 0.19 & $1.09 * *$ & 15.54 & $0.64 * *$ & $-21.45^{* *}$ & $31.84 * *$ \\
\hline $\mathrm{P}_{3} \times \mathrm{P}_{8}$ & 0.16 & -3.93 & -3.81 & $2.08 * *$ & $0.66^{* *}$ & 0.13 & $204.04 * *$ & $-0.13 * *$ & $-6.08 * *$ & $50.24 * *$ \\
\hline $\mathrm{P}_{4} \times \mathrm{P}_{5}$ & $-6.79 *$ & -0.39 & -0.38 & $1.38 *$ & $-1.80 * *$ & $-0.59 * *$ & $-283.36 * *$ & $0.91 * *$ & $17.59 * *$ & $-82.99 * *$ \\
\hline $\mathrm{P}_{4} \times \mathrm{P}_{6}$ & -1.86 & -0.73 & -0.06 & $1.92 * *$ & $-0.42 *$ & 0.20 & -30.83 & $-0.70 * *$ & 0.95 & $179.68 * *$ \\
\hline $\mathrm{P}_{4} \times \mathrm{P}_{7}$ & 1.50 & -2.49 & -2.81 & -0.87 & -0.15 & $-0.61 * *$ & -50.89 & $0.36^{* *}$ & $4.55 * *$ & $-0.35 * *$ \\
\hline $\mathrm{P}_{4} \times \mathrm{P}_{8}$ & -2.35 & 1.04 & 1.69 & -1.00 & -0.05 & 0.21 & $-123.06 * *$ & $1.34 * *$ & $18.42 * *$ & $-16.14 * *$ \\
\hline $\mathrm{P}_{5} \times \mathrm{P}_{6}$ & -4.83 & -1.93 & -2.01 & $-3.57 * *$ & $0.90 * *$ & $0.50^{* *}$ & $-195.53 * *$ & $0.75^{* *}$ & $37.40^{* *}$ & $-63.66 * *$ \\
\hline $\mathrm{P}_{5} \times \mathrm{P}_{7}$ & 4.24 & -4.36 & -5.54 & 0.33 & -0.18 & $0.37 *$ & -53.93 & $0.34 * *$ & $28.04 * *$ & $-53.50 * *$ \\
\hline $\mathrm{P}_{5} \times \mathrm{P}_{8}$ & 2.27 & 0.51 & 1.62 & $2.12 * *$ & $0.65^{* *}$ & 0.22 & $126.24 * *$ & $-0.16 * *$ & $-41.52^{* *}$ & $53.89 * *$ \\
\hline $\mathrm{P}_{6} \times \mathrm{P}_{7}$ & -1.72 & -0.36 & -0.22 & -0.75 & -0.30 & $-1.14 * *$ & $297.61 * *$ & $-0.70 * *$ & 2.26 & $-90.68 * *$ \\
\hline $\mathrm{P}_{6} \times \mathrm{P}_{8}$ & $-7.78 * *$ & -3.16 & -4.61 & 0.64 & -0.32 & 0.26 & $123.77 * *$ & $0.40^{* *}$ & $-15.67 * *$ & $-82.26^{* *}$ \\
\hline $\mathrm{P}_{7} \times \mathrm{P}_{8}$ & $9.85 * *$ & $-5.59 *$ & $-5.81 *$ & $2.78 * *$ & $0.92 * *$ & $1.56^{* *}$ & $61.37 *$ & $0.12 * *$ & $5.43 * *$ & $103.44 * *$ \\
\hline SE (Sij) & 5.62 & 5.53 & 5.68 & 1.22 & 0.41 & 0.32 & 54.85 & 0.05 & 2.72 & 5.76 \\
\hline $\begin{array}{l}\text { SE (Sij- } \\
\text { Sik) }\end{array}$ & 8.32 & 8.18 & 8.40 & 1.80 & 0.60 & 0.47 & 81.15 & 0.07 & 4.02 & 8.53 \\
\hline
\end{tabular}

*,** denote significant at 5 and 1 per cent probability level, respectively

Where, $\mathrm{P}_{1}=$ Swarna Pratibha, $\mathrm{P}_{2}=$ NDB-3, $\mathrm{P}_{3}=$ Pant Rituraj, $\mathrm{P}_{4}=$ Pusa Purple Long, $\mathrm{P}_{5}=\mathrm{BR}-112, \mathrm{P}_{6}=\mathrm{CHFB}-6, \mathrm{P}_{7}=$

CHFB-7 and $\mathrm{P}_{8}=$ Solanum gilo

Specific combining ability effects of the hybrids

Magnitudes of sca effects in the hybrids were in low $\mathrm{x}$ low, high $\mathrm{x}$ low, average $\mathrm{x}$ low average $\mathrm{x}$ high and high $\mathrm{x}$ high for all the characters. For plant height, Pant Rituraj $\mathrm{x}$ CHFB-6 (0.49) and CHFB-7x Solanum gilo (0.62) showed significant specific combining ability effects. The findings for plant height were also in accordance with Suneetha et al., (2008) (Table 3).

CHFB-7 x Solanum gilorecorded the high significant sca effects for days to first flowering and days to first fruit harvest. For
Fruit length, NDB-3 x Solanum gilofound significant high sca effects followed by Pant Rituraj $x$ Pusa Purple Long, CHFB-7x Solanum gilo, NDB-3 x BR-112, Pant Rituraj $\mathrm{x}$ Solanum gilo. However for fruit width, Swarna Pratibha x Pusa Purple Long, Swarna Pratibha x BR-112 and CHFB-7 x Solanum gilo showed high sca effects with positive significant value. Dubey et al., (2014) also reported the similar results for fruit length and girth. The high sca effects for number of seeds per fruit were found in the hybrids Swarna Pratibha x BR-112, Swarna Pratibha x Pusa Purple Long, Pant Rituraj x BR-112, CHFB-6 x CHFB-7 and Pant Rituraj $\mathrm{x}$ Solanum gilo. Pant Rituraj x CHFB-6 
established the significant sca effects for fruit yield per plant with value of 0.47 followed by CHFB-7x Solanum gilo, Pant Rituraj $\mathrm{x}$ CHFB-7 and Swarna Pratibha $x$ NDB-3.The magnitude of sca effects for fruit yield per plant have been also reported by Mishra et al., (2013).Among the hybrids, Pusa Purple Long x Solanum gilo, BR-112 x CHFB-6, Pusa Purple Long x BR-112 and Pant Rituraj X CHFB-7 were observed high sca effects for solasodine content. For total phenol content, NDB-3 x Pant Rituraj, Swarna Pratibha $x$ Pusa Purple Long, BR-112 x CHFB-6, NDB$3 \times$ Pusa Purple Long and Swarna Pratibha $x$ BR-112 were recorded high significant sca effects in desirable direction. These kind of trend was also reported by Kumar et al., (2012) and Desai et al., (2017).

Among the hybrids, Pant Riturajx CHFB-6 and Pant Riturajx CHFB-7found significant positive high sca effects for plant height, fruit yield per plant, number of seeds per fruit, solasodine content and anthocyanin content. The significant sca effects were observed for plant height, days to first flowering, days to first fruit harvest, fruit length, fruit girth, fruit yield per plant, number of seed per fruit, solasodine content, total phenol content and anthocyanin content in hybrid CHFB-7 $\mathrm{x}$ Solanum gilo. Swarna Pratibha x Pusa Purple Long have a high sca effect for fruit length, fruit girth, fruit yield per plant, number of seeds per fruit, total phenol content and anthocyanin content.

Hence, parents CHFB-6, Pant Rituraj, Swarna Pratibha and BR-112 were identified as the most promising parents for fruit yield per plant along with earliness and quality traits. The hybrids, Pant Riturajx CHFB-6,,CHFB-7 $\mathrm{x}$ Solanum gilo, Pant Riturajx CHFB-7 and Swarna Pratibha $x$ Pusa Purple Long were the most promising for improvement of most of traits including fruit yield, earliness and quality traits. These crosses having significant sca effects involved either at least one of the parent as low or high general combiner for fruit yield and other characters. Selected parents with desirable per se and general combining ability effects can be used in varietal improvement programmes and multiple crossing schemes to improve quantity and quality components. It is suggested to test the superior hybrids with few more in multi-location trial to confirm their potentiality and stability over different agro-climatic conditions.

\section{References}

Anonymous, 2014. Annual report of National Horticulture Database.

Ansari, A.M., and Singh, Y. V. 2014.Combining ability analysis for vegetative, physiological and yield components in brinjal (Solanum melongena L.). International Science Journal. 1(2): 53-59.

Desai, K.M., Saravaiya, S.N. and Patel, D.A. 2017.Combining ability for yield and different characters in brinjal (Solanum melongena L.). Electronic Journal of Plant Breeding, 8(1): 311-315.

Dharwad, N.A., Patil, S.A. and Salimath, P.M. (2011).Heterosis and combining ability analysis for productivity traits in brinjal (Solanum melongena L.). Karnataka Journal of Agriculture Sciences, 24(5): 622-625.

Dubey, R., Das, A., Ojha, M. D., Saha, B., Ranjan, A. and Singh, P. K. 2014.Heterosis and combining ability studies for yield and yield attributing traits in brinjal (Solanum melongena L.). The Bioscan. 9(2): 889-894.

Gomez, K.A., and Gomez, A.A. 1983. Statistical procedure for agricultural research 2nd ed., John Wiley and Sons, New York. pp. 375-427.

Griffing, B., 1956.Concept of general and specific combining ability in relation to 
diallel crossing system. Australian Journal of Biological Sciences, 9: 465493.

Kumar, S. R., and Arumugam, T. 2013. Gene action and combining ability analysis in brinjal (Solanum melongena L.). $J$. Hortl. Sci. 8(2):249-254.

Kumar, S. R., Arumugam, T., Anandakumar, C. R. and Rajavel, D.S. 2012.Estimation of Heterosis and Specific Combining Ability for Yield, Quality, Pest and Disease Incidence in Eggplant (Solanum melongena L.). Bulletin of Environment, Pharmacology and Life Sciences. 2 (1): 03- 15.

Mishra, R., Singh, A.K., Manju Vani V., Singh, B.K., Kumar, H. and Rajkumar, B.V. 2013. Combining ability studies in elite breeding lines of brinjal (Solanum melongena L.) for plant characters. Asian Journal of Biological and Life Sciences. 2(3): 275-278.

Nwodo, S.C., Abayomi, C.O., Eboji, O.K., Opeyemi, C.E., Olajumoke, A.K. and Damilola, I.D. 2011.Proximate and phytochemical analysis of Solanum aethiopicum L. and Solanum macrocarpon L. fruits. Research Journal of Chemical Sciences 1(3):436439.

Nyadanu, D., and Lowor, S.T. 2015. Promoting competitiveness of neglected and underutilized crop species: Comparative analysis of nutritional composition of indigenous and exotic leafy and fruit vegetables in Ghana. Genetic Resourcesand Crop Evolution 62(1):131-140.

Sharma, T. K., Pant, S. C., Kumar, S., Paliwal, A., Bahuguna, P. and Badhani, H. C. 2016. Combining Ability Studies in Brinjal (Solanum melongena L.) International Journal of Bio-resource and Stress Management.7 (6):12251231.

Sherly, J., 2007. Evaluation of local types of eggplant (Solanum melongenaL.). M.Sc., (Hort.) Thesis, Pandit Jawaharlal Nehru College of Agriculture and Research Institute, Karaikal.

Singh, R., and Maurya A. N. 2004.Combining ability studies for number and weight of marketable fruits in brinjal (Solanum melongenaL.).Prog. Hort. 36(2): 350355.

Suneetha, Y., Kathiria, K.B., Patel, J.S., and Srinivas, T. 2008. Studies on heterosis and combining ability in late summer brinjal. Indian J. Agric. Res. 42(3): 171176.

Uddin, M. S., Rahman, M.M., Hossain, M.M., Mian, M.A. K. 2015. Combining ability of yield and yield components in Eggplant (Solanum melongena L.) during summer. Universal Journal of Plant Science. 3(4): 59-66.

\section{How to cite this article:}

Yadav, P.K., R.K. Dubey, Sanket Kumar, Yadav Ram and Maneesh Kumar Singh. 2017. Implications of Combining Ability among the Single Cross Hybrids for Yield and Quality Attributes in Brinjal (Solanum melongena L.). Int.J.Curr.Microbiol.App.Sci. 6(10): 3424-3429. doi: https://doi.org/10.20546/ijcmas.2017.610.403 